\begin{tabular}{|c|c|c|c|c|c|c|c|c|}
\hline \multicolumn{3}{|c|}{$\begin{array}{l}\text { 2. To: (Receiving Organization) } \\
\text { Distribution }\end{array}$} & \multicolumn{2}{|c|}{$\begin{array}{l}\text { 3. From: (Originating Organization) } \\
\text { SNF Project }\end{array}$} & \multicolumn{4}{|c|}{$\begin{array}{r}\text { 4. Related EDT No.: } \\
\text { N/A }\end{array}$} \\
\hline \multicolumn{3}{|c|}{$\begin{array}{l}\text { 5. Proj./Prog./Dept/Div.: } \\
\text { Spent Nuclear Fuel Project }\end{array}$} & \multicolumn{2}{|c|}{$\begin{array}{l}\text { 6. Design Authority/ Design Agent/Cog. } \\
\text { Engr.: } \\
\text { C. Van Katwijk }\end{array}$} & \multicolumn{4}{|c|}{ 7. Purchase Order No.: } \\
\hline \multicolumn{5}{|c|}{$\begin{array}{l}\text { 8. Originator Remarks: } \\
\text { N/A }\end{array}$} & \multicolumn{4}{|c|}{ 9. Equip./Component No.: } \\
\hline & \multicolumn{4}{|c|}{$\begin{array}{l}\text { 10. System/Bidg./Facility: } \\
\text { Spent Nuclear Facility }\end{array}$} \\
\hline \multirow{3}{*}{\multicolumn{3}{|c|}{ 11. Receiver Remarks: }} & \multirow{3}{*}{\multicolumn{2}{|c|}{ eline Document? [] Yes [X] No }} & \multicolumn{4}{|c|}{$\begin{array}{l}\text { 12. Major Assm. Dwg. No.: } \\
\text { N/A }\end{array}$} \\
\hline & & & & & \multicolumn{4}{|c|}{$\begin{array}{l}\text { 13. Permit/Permit Application No.: } \\
\text { N/A }\end{array}$} \\
\hline & & & & & \multicolumn{4}{|c|}{$\begin{array}{l}\text { 14. Required Response Date: } \\
\text { N/A }\end{array}$} \\
\hline 15. & \multicolumn{4}{|c|}{ DATA TRANSMITTED } & \multirow{2}{*}{$\begin{array}{c}\text { (F) } \\
\begin{array}{c}\text { Approval } \\
\text { Desig- } \\
\text { nator }\end{array}\end{array}$} & \multirow{2}{*}{$\begin{array}{l}\text { (G) } \\
\text { Reason } \\
\text { for } \\
\text { Trans- } \\
\text { mittal }\end{array}$} & \multirow{2}{*}{$\begin{array}{c}(\mathrm{H}) \\
\text { Origi- } \\
\text { nator } \\
\text { Dispo- } \\
\text { sition }\end{array}$} & \multirow{2}{*}{$\begin{array}{l}\text { (1) } \\
\text { Receiv- } \\
\text { er } \\
\text { Dispo- } \\
\text { sition }\end{array}$} \\
\hline $\begin{array}{l}\text { (A) } \\
\text { Item } \\
\text { No. }\end{array}$ & (B) Document/Drawing No. & $\begin{array}{l}\text { (C) } \\
\text { Sheet } \\
\text { No. }\end{array}$ & $\begin{array}{l}\text { (D) } \\
\text { Rev. } \\
\text { No. }\end{array}$ & $\begin{array}{l}\text { (E) Title or Description of Data } \\
\text { Transmitted }\end{array}$ & & & & \\
\hline 1 & SNF-3889 & & 0 & $\begin{array}{l}\text { Rosemount Indicator/Transmitter - } \\
\text { Helium Supply Pressure to the MCO }\end{array}$ & $Q$ & 2 & 1 & $\mathrm{~N} / \mathrm{A}$ \\
\hline & & & & & & & & \\
\hline & & & & & & & & \\
\hline & & & & & & & & \\
\hline & & & & & & & & \\
\hline
\end{tabular}

16.

KEY

\begin{tabular}{|c|c|c|c|c|}
\hline Approval Designator $(F)$ & & Reason for Transmittal (G) & \multicolumn{2}{|c|}{ Disposition (H) \& (I) } \\
\hline $\begin{array}{l}\text { E, S, Q, D or N/A } \\
\text { (see WHC-CM-3-5, } \\
\text { Sec. 12.7) }\end{array}$ & $\begin{array}{l}\text { 1. Approval } \\
\text { 2. Release } \\
\text { 3. Information }\end{array}$ & $\begin{array}{l}\text { 4. Review } \\
\text { 5. Post-Review } \\
\text { 6. Dist. (Receipt Acknow. Required) }\end{array}$ & $\begin{array}{l}\text { 1. Approved } \\
\text { 2. Approved w/comment } \\
\text { 3. Disapproved w/comment }\end{array}$ & $\begin{array}{l}\text { 4. Reviewed no/comment } \\
\text { 5. Reviewed w/comment } \\
\text { 6. Receipt acknowledged }\end{array}$ \\
\hline
\end{tabular}
17. SIGNATURE/DISTRIBUTION

(See Approval Designator for required signatures)

\begin{tabular}{|c|c|c|c|c|c|c|}
\hline $\begin{array}{l}\text { (G) } \\
\text { Rea- } \\
\text { son }\end{array}$ & $\begin{array}{l}\text { (H) } \\
\text { Disp. }\end{array}$ & $\begin{array}{llll}\text { (J) Name } & \text { (K) Signature (L) Date } & \text { (M) MSIN }\end{array}$ & $\begin{array}{l}\text { (G) } \\
\text { Rea- } \\
\text { Son }\end{array}$ & $\begin{array}{l}\text { (H) } \\
\text { Disp. }\end{array}$ & (J) Name & (K) Signature (L) Date (M) MSIN \\
\hline 2 & 1 & Designated Engineer C. Van Katwijk & & & & \\
\hline 2 & 1 & Design Authority R. Whitchurst $(2) \sqrt{2} 3 \sqrt{3}$ & & & & \\
\hline 2 & 1 & QA T.D. Hays TO Idaye $3 / 30 / 99^{\circ}$ & & & & \\
\hline & & & & & & \\
\hline & & & & & & \\
\hline & & & & & & \\
\hline & & & & & & \\
\hline
\end{tabular}

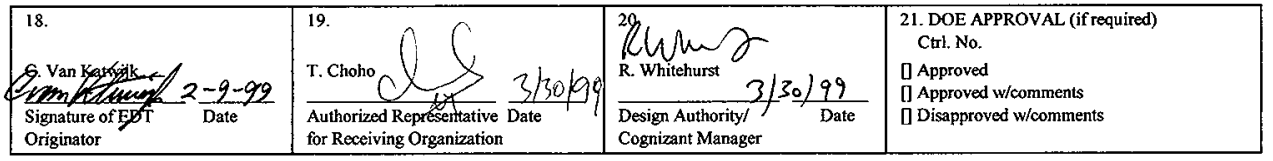




\section{Rosemount Indicator / Transmitter - Helium Supply Pressure to the $\mathrm{MCO}$}

Carl Van Katwijk

Numatec Hanford Co, Richland, WA 99352

U.S. Department of Energy Contract DE-AC06-96RL13200

EDT/ECN: 626262

Org Code: $2 \mathrm{G} 300$

B\&R Code: $39 \mathrm{EW} 40400$
UC: 620

Charge Code: $105559 / \mathrm{A} 00$

Total Pages: 14

Key Words: Pressure Indicator / Transmitter - MCO

Abstract: Rosemount Indicator / Transmitter - Helium supply Pressure to the MCO CGI-SNF-D-13-P4-013

TRADEMARK DISCLAIMER. Reference herein to any specific commercial product, process, or service by trade name, trademark, manufacturer, or otherwise, does not necessarily constitute or imply its endorsement, recommendation, or favoring by the United States Govermment or any agency thereof or its contractors or subcontractors.

Printed in the United States of America. To obtain copies of this document, contact: Document Controlseapices.PQQBox 950, Mailstop H6-08, Richland WA 99352, Phone (509) 372-2420; Fax (509) 376-4989. 
Commercial Grade Item Upgrade Dedication Form

Title: ROSEMOUNT INDICATOR/TRANSMITTER - HELIUM SUPPLY PRESSURE TO THE MCO

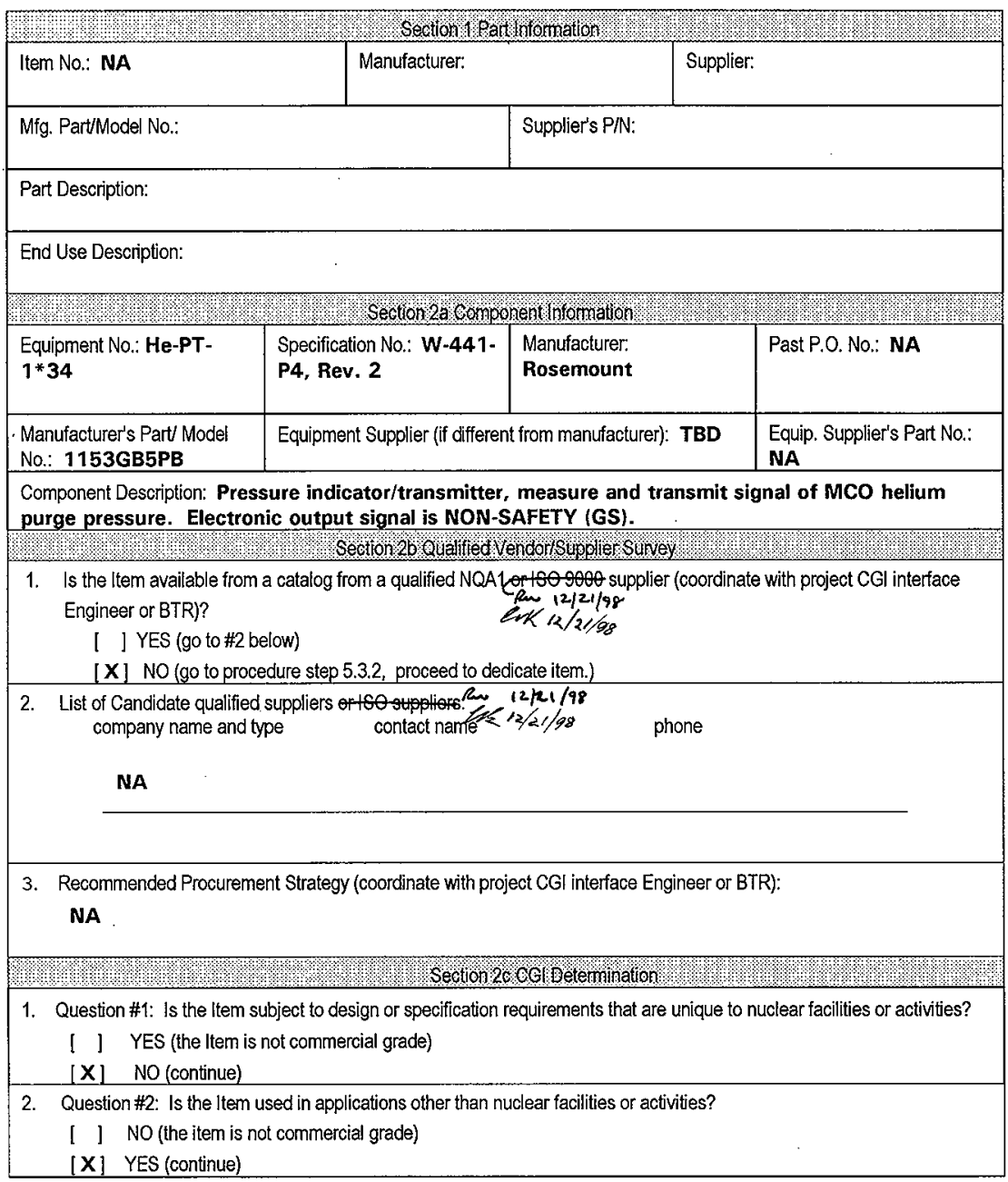


Title: ROSEMOUNT INDICATOR/TRANSMITTER - HELIUM SUPPLY PRESSURE TO THE MCO

3. Question \#3: Is the Item ordered from manufacturer/supplier on the basis or specifications set forth in the manufacturers catalog?

[ I NO (the ltem is not commercial grade)

[X] YES (continue)

[X] All three criteria have been satisfied. The ltem meets the definition of commercial grade.

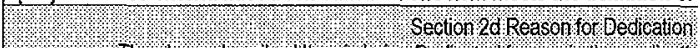

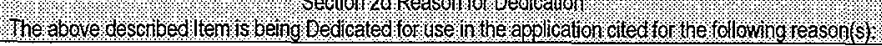

[X] Item is being purchased from a non ESL manufacturer supplier as commercial grade to be used in a Safety Class application.

[ ] Item is being purchased from a non ESL manufacturer supplier as commercial grade to be used in a Safety Significant application.

[ ] item was purchased from a non ESL manufacturer supplier as commercial grade to be used in a Safely Class application.

[ ] Item was purchased from a non ESL manufacturer supplier as commercial grade to be used in a Safety Significant application.

L l Other ('ike-for-like', similar, substitution, replacement evaluation)

Section 3 . alu ure Etfecs Evaluation

A. Par//Component Safety Function:

1. Pressure Boundary Integrity, Confinement

\section{Maintain Pressure Boundary After Seismic Event}

3.

B. Part/Component Functional Mode:

Safety Function \#1:

[ ] Active - Mechanical or Electrical change of state is required to occur for the component to perform its safety function

[X] Passive - Change of state is not required for the component to perform its safety function Safety Function \#2:

[ ] Active-Mechanical or Electrical change of state is required to occur for the component to perform its safety function.

[X] Passive - Change of state is not required for the component to perform its safely function Safety Function \#3:

1 ] Active - Mechanical or Electrical change of state is required to occur for the component to perform its safety function.

[ ] Passive - Change of state is not required for the component to perform its safety function

\section{Host Component Safety Function (if applicable):}

1. NA

2.

3. 
D. Failure Mechanisms(s) and the effects on component or system safety function (see worksheet 1):

1. PI process connection break/PI body break - inleakage of air/ release of MCO contents through the pressure boundary.

\section{4. \\ 5.}

2.

3 .

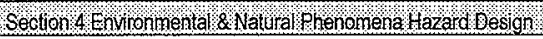

Environmental Qualification Required:

If yes: Environmental Qualification Requirements

Yes [ I

No $[\mathbf{X}]$

Environmental Condition B

Natural Phenomena Hazard (NPH) Design Required:

$$
\text { Yes [X] }
$$$$
\text { No [ ] }
$$

HNF-PRO-97, Rev. 0

W-441-P4, Rev. 2
Limiting Environmental Conditions:

Required Safely Functions:

Qualification Period:

If yes: NPH Design Requirements

Performance Category: PC-3

NPH Design Req'ts.: Seismic Condition B

Required Safety Functions: Pressure Boundary Integrity, Confinement

\section{Section 5 Component tunctional Classification}

[ ]General Service

I I Safety Significant (SS)

If part/component classification is different from host component/system, document basis.

\begin{tabular}{|c|c|c|}
\hline \%. & 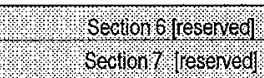 & 4 \\
\hline $\begin{array}{l}\text { National Codes/Standards: IEEE 344, } \\
\text { ISA-S5.1, S5.4, S18.1, S20 }\end{array}$ & $\begin{array}{l}\text { Safety Analysis Report (SAR): } \\
\text { HNF-SD-SNF-SAR-002, } \\
\text { Rev. 4A }\end{array}$ & $\begin{array}{l}\text { Drawings: H-1-82161, Rev. } 2 \\
\text { HNF-SD-SNF-SEL-002, Rev. } 4\end{array}$ \\
\hline
\end{tabular}

Vendor Manuals/Manufacturer/Supplier Information: Rosemount Pressure Transmitter Model 1153

Other: 
Commercial Grade Item Upgrade Dedication Form

ECN No. NA CGI No. CGI-SNF-D-13-P4-013

Title: ROSEMOUNT INDICATOR/TRANSMUTTER - HELIUM SUPPLY PRESSURE TO THE MCO
Rev. No. 0

Page 4 of 13

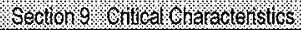

Critical Characteristics

Verification Document: VENDOR SPECIFICATIONS.

HNF-SD-SNF-SEL-002, Rev. 4

1. Item Identification Critical Characteristics (necessary for reasonable assurance that the Item delivered is the Item specified)

\begin{tabular}{|l|l|l|l|l|}
\hline Nameplate Data & Per Vendor Manual & $1, I N$ & $x$ & \\
\hline Model Number & $1153 G B 5 P B$ & $1, I N$ & $x$ & \\
\hline Enclosure Class & NEMA-4X & $1, I N$ & $x$ & \\
\hline Manufacturer & Rosemount & $1, I N$ & $x$ & \\
\hline Process Connection & $1 / 4-18$ NPT & $1, I N$ & $x$ & \\
\hline
\end{tabular}

2. Physical Critical Characteristics (necessary for reasonable assurance that the Item delivered is the ltem specified)

\begin{tabular}{|l|l|l|l|l|}
\hline Material, Body & Stainless Steel & $1, T$ & $X$ & \\
\hline Material, Process Connection & Stainless Steel & $1, T$ & $X$ & \\
\hline Indicator, LCD Display & $0-100 \%$ & $1, I N$ & $X$ & \\
\hline Bracket & Panel Mount & $1, I N$ & $X$ & \\
\hline
\end{tabular}

3. Performance Critical Characteristics (necessary \& sufficient for reasonable assurance that the ltem will perform its intended safety function(s))

\begin{tabular}{|l|l|l|l|l|}
\hline Pressure Boundary Integrity & $\begin{array}{l}\text { No Leakage at Test Pressure of } \\
165 \text { Psig. Note 2. }\end{array}$ & 1,T \\
\hline Insulation Resistance & NA & & & \\
\hline Operating Range & NA & & & \\
\hline Repeatability & NA & & & \\
\hline Environmental & Note 1 & & & \\
\hline Seismic Condition B & Note 3 & $1, T$ & & X \\
\hline Operating Range & NA & & \\
\hline
\end{tabular}


1. The pressure indicator is not subject to degradation at ambient conditions of $40^{\circ} \mathrm{F}$ and $60 \% \mathrm{RH}$ or $115^{\circ} \mathrm{F}$ and $22 \% \mathrm{RH}$ and is suitable for Environmental Condition $\mathrm{B}$ application.

2. Pressure test at $110 \%$ of design accident condition pressure of 150 psig. Exposure to this pressure may seriously degrade the reading function. This test is considered to be a destructive test.

3. Maintain pressure boundary after Seismic event. W-441-P4, Rev. 2, Appendix L, page L-14, provides a seismic testing plan for these components at a (TBD) seismic spectra.

"Confinement" leakage acceptance criteria is $<10^{-4} \mathrm{scc} / \mathrm{sec}$.

\section{(1.7. Seclon 10 . nitil Revow ond A poroval}

Approvals:

Designated Engineer: 2 rm theres 42/2/88

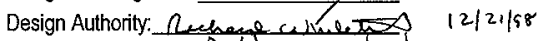

QA Engineer: Tr Dtap 12/22198 


ECN No. NA CGI No.CGI-SNF-D-13-P4-013
Title: ROSEMOUNT INDICATOR/TRANSMITTER - HELIUM SUPPLY
PRESSURE TO THE MCO

Page 6 of 13 PRESSURE TO THE MCO

\begin{tabular}{|c|c|c|}
\hline \multicolumn{3}{|c|}{$\begin{array}{c}\text { WORKSHEET } 1 \\
\text { DETERMINATION OF FAILURE MECHANISMSMODES }\end{array}$} \\
\hline \multicolumn{3}{|c|}{ 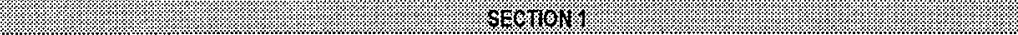 } \\
\hline $\begin{array}{l}\text { Typical Failure } \\
\text { Mechanisms }\end{array}$ & Definition & $\begin{array}{c}\text { Applicable to Component } \\
\text { under Evaluation }\end{array}$ \\
\hline Fracture & $\begin{array}{l}\text { Separation of a solid accompanied by little or no } \\
\text { macroscopic plastic deformation. }\end{array}$ & $\begin{array}{l}\text { Yes [ ] No [X]; If Yes, indicate } \\
\text { failure Mode. }\end{array}$ \\
\hline Corrosion & $\begin{array}{l}\text { The gradual deterioration of a material due to } \\
\text { chemical or electrochemical reactions, such as }\end{array}$ & $\begin{array}{l}\text { Yes [ ] No [X]; if Yes, indicate } \\
\text { failure Mode. }\end{array}$ \\
\hline Erosion & $\begin{array}{l}\text { Destruction of materials by the abrasive action of } \\
\text { moving fluids, usually accelerated by the presence } \\
\text { of solid particles carried with the fluid. }\end{array}$ & $\begin{array}{l}\text { Yes [ ] No [X]; If Yes, indicate } \\
\text { failure Mode. }\end{array}$ \\
\hline Open Circuit & $\begin{array}{l}\text { An electrical circuit that is unintentionally broken so } \\
\text { that there is no complete path for current flow. }\end{array}$ & $\begin{array}{l}\text { Yes [ ] No [X]; lf Yes, indicate } \\
\text { failure Mode. }\end{array}$ \\
\hline Short Circuit & $\begin{array}{l}\text { An abnormal connection by which an electrical } \\
\text { current is connected to ground, or to some }\end{array}$ & $\begin{array}{l}\text { Yes [ ] No [X]; If Yes, indicate } \\
\text { failure Mode. }\end{array}$ \\
\hline Blockage & $\begin{array}{l}\text { conducting body, resulting in excessive current flow. } \\
\text { Clogging of a filtering medium resulting in the } \\
\text { inability to perform its purification function or } \\
\text { blockage of flow. }\end{array}$ & $\begin{array}{l}\text { Yes [ ] No [X]; If Yes, indicate } \\
\text { failure Mode. }\end{array}$ \\
\hline Seizure & $\begin{array}{l}\text { Binding of a normally moving item through excessive } \\
\text { pressure, temperature, friction, jamming. }\end{array}$ & $\begin{array}{l}\text { Yes [ ] No [X]; If Yes, indicate } \\
\text { failure Mode. }\end{array}$ \\
\hline Unacceptable Vibration & $\begin{array}{l}\text { Mechanical oscillations produced are beyond the } \\
\text { defined permissible limits due to unbalancing, poor } \\
\text { support, or rotation at critical speeds. }\end{array}$ & $\begin{array}{l}\text { Yes [ ] No [X]; If Yes, indicate } \\
\text { failure Mode. }\end{array}$ \\
\hline Loss of Properties & $\begin{array}{l}\text { A loss of mechanical and physical properties of a } \\
\text { material due to exposure to high temperatures, } \\
\text { radiation exposure. }\end{array}$ & $\begin{array}{l}\text { Yes [ ] No [X]; If Yes, indicate } \\
\text { failure Mode. }\end{array}$ \\
\hline Excess Strain & $\begin{array}{l}\text { Under the action of excessive external forces the } \\
\text { material of the part has been deformed or distorted. }\end{array}$ & $\begin{array}{l}\text { Yes [ ] No [X]; if Yes, indicate } \\
\text { failure Mode. }\end{array}$ \\
\hline Mechanical Creep & $\begin{array}{l}\text { From prolonged exposure to high temperature and } \\
\text { stress, the object will show a slow change in its } \\
\text { physical (shape and dimension) and mechanical }\end{array}$ & $\begin{array}{l}\text { Yes [ ] No [X]; If Yes, indicate } \\
\text { failure Mode. }\end{array}$ \\
\hline Ductile Fracture & $\begin{array}{l}\text { characteristics. } \\
\text { Fracture characterized by tearing of metal } \\
\text { accompanied by appreciable gross plastic } \\
\text { deformation. }\end{array}$ & $\begin{array}{l}\text { Yes [ ] No [X]; If Yes, indicate } \\
\text { failure Mode. }\end{array}$ \\
\hline \multicolumn{3}{|c|}{ 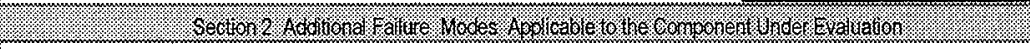 } \\
\hline \multicolumn{3}{|c|}{ 1. Gauge Movement Mechanism Failure } \\
\hline \multicolumn{3}{|c|}{ 2. Process Connection/Body Break } \\
\hline
\end{tabular}


Commercial Grade Item Upgrade Dedication Form ECN No. NA CGI No. CGI-SNF-D-13-P4-013

Title: ROSEMOUNT INDICATOR/TRANSMITTER - HELIUM SUPPLY PRESSURE TO THEMCO

\section{CHECKLIST 1}

\section{ACCEPTANCE METHOD 1}

SPECIAL TEST/INSPECTION VERIFICATION

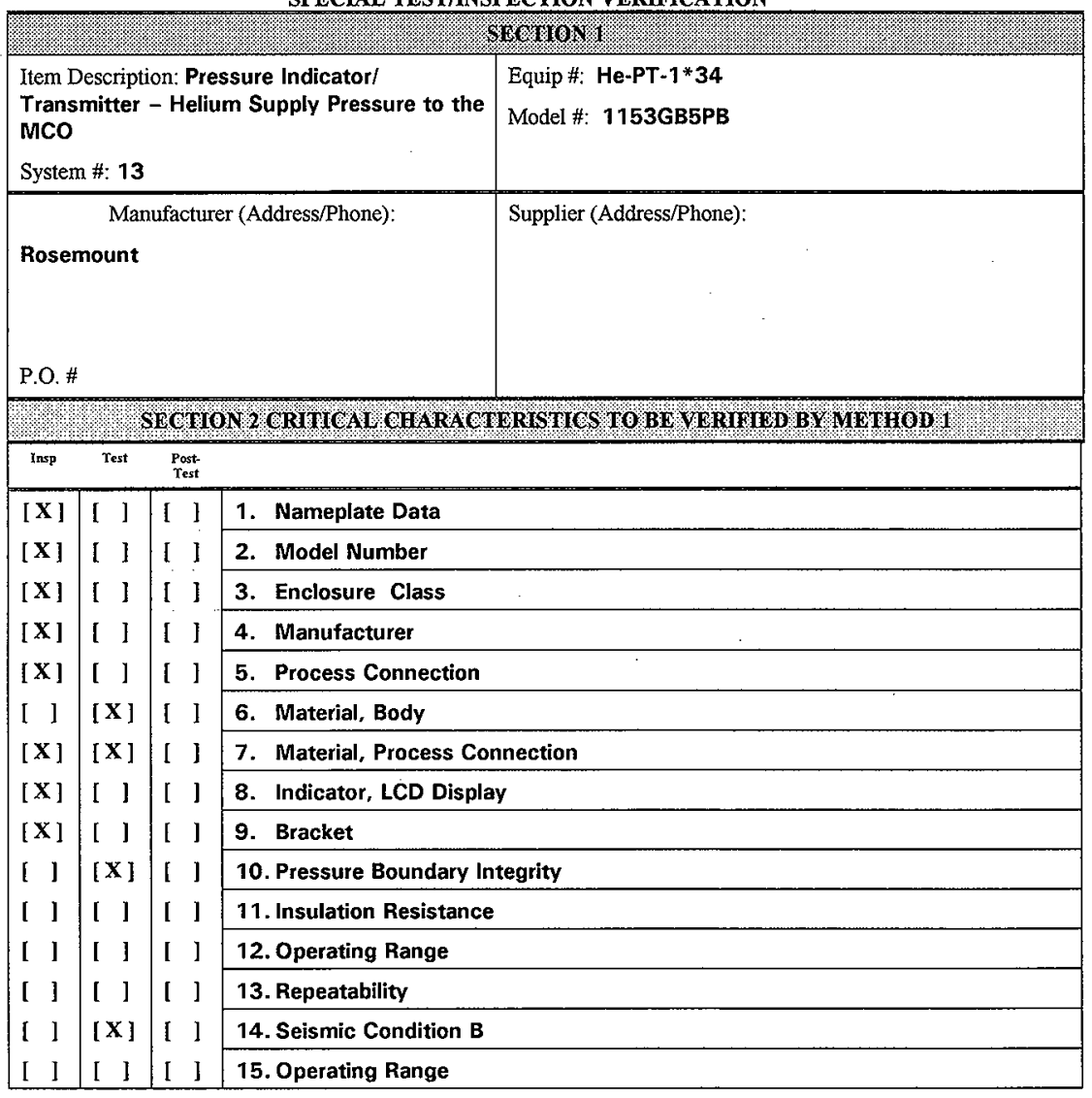


Title: ROSEMOUNT INDICATOR/TRANSMITTER - HELIUM SUPPLY

PRESSURE TO THE MCO

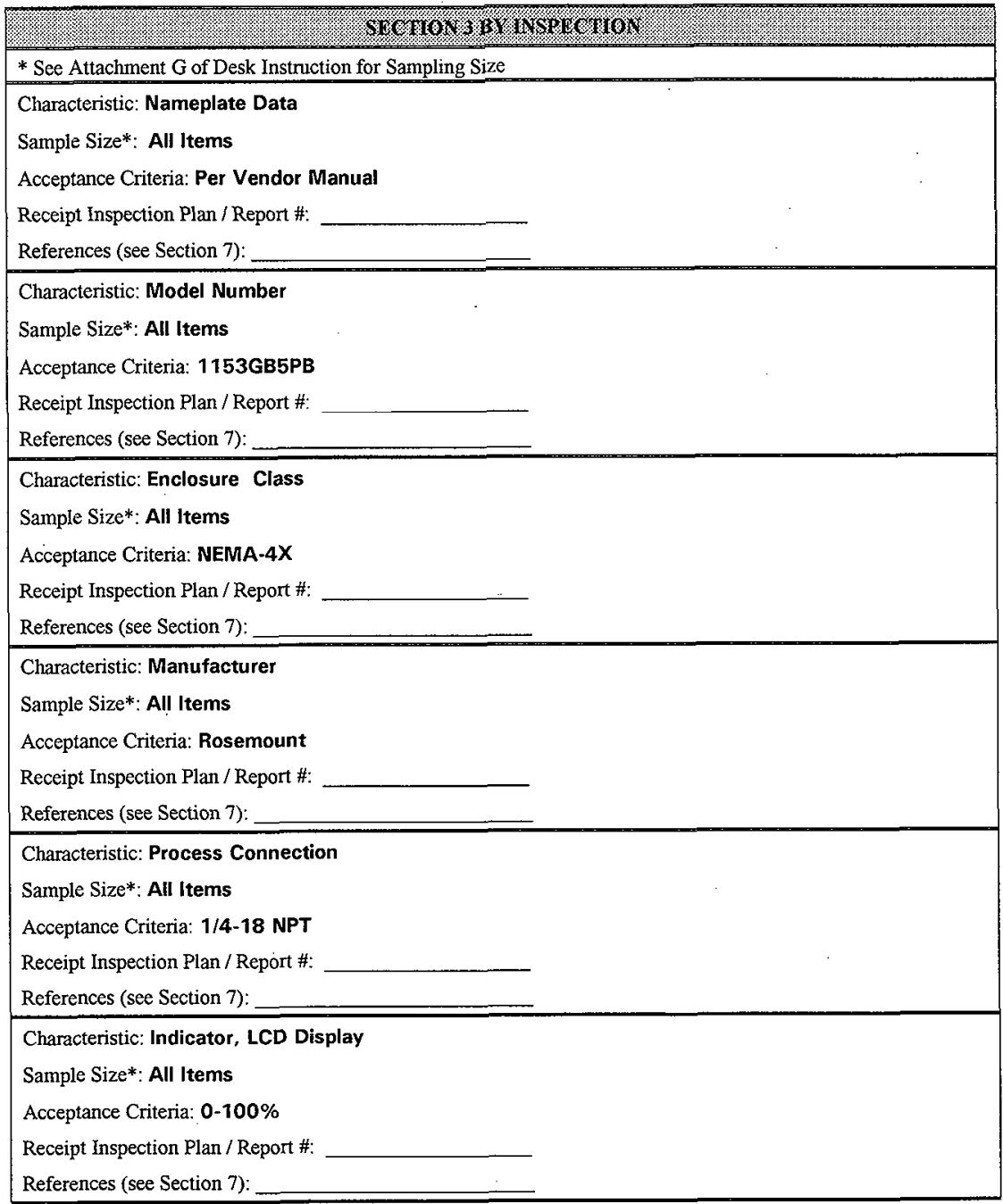


Title: ROSEMOUNT INDICATOR/TRANSMITTER - HELIUM SUPPLY PRESSURE TO THE MCO

Characteristic for Test:

Acceptance Criteria:

Sample Size*:

Actual Test Value:

Test Plan and Report \#: References (see Section 7):

Characteristic for Test

Acceptance Criteria:

Sample Size*:

Actual Test Value:

Test Plan and Report \#: References (see Section 7):

Characteristic for Test:

Acceptance Criteria: .

Sample Size*:

Actual Test Value:

Test Plan and Report \#: References (see Section 7):

* If Supplier/Manufacturer or Other, Refer to CGI Checklist-2 for Support Information 


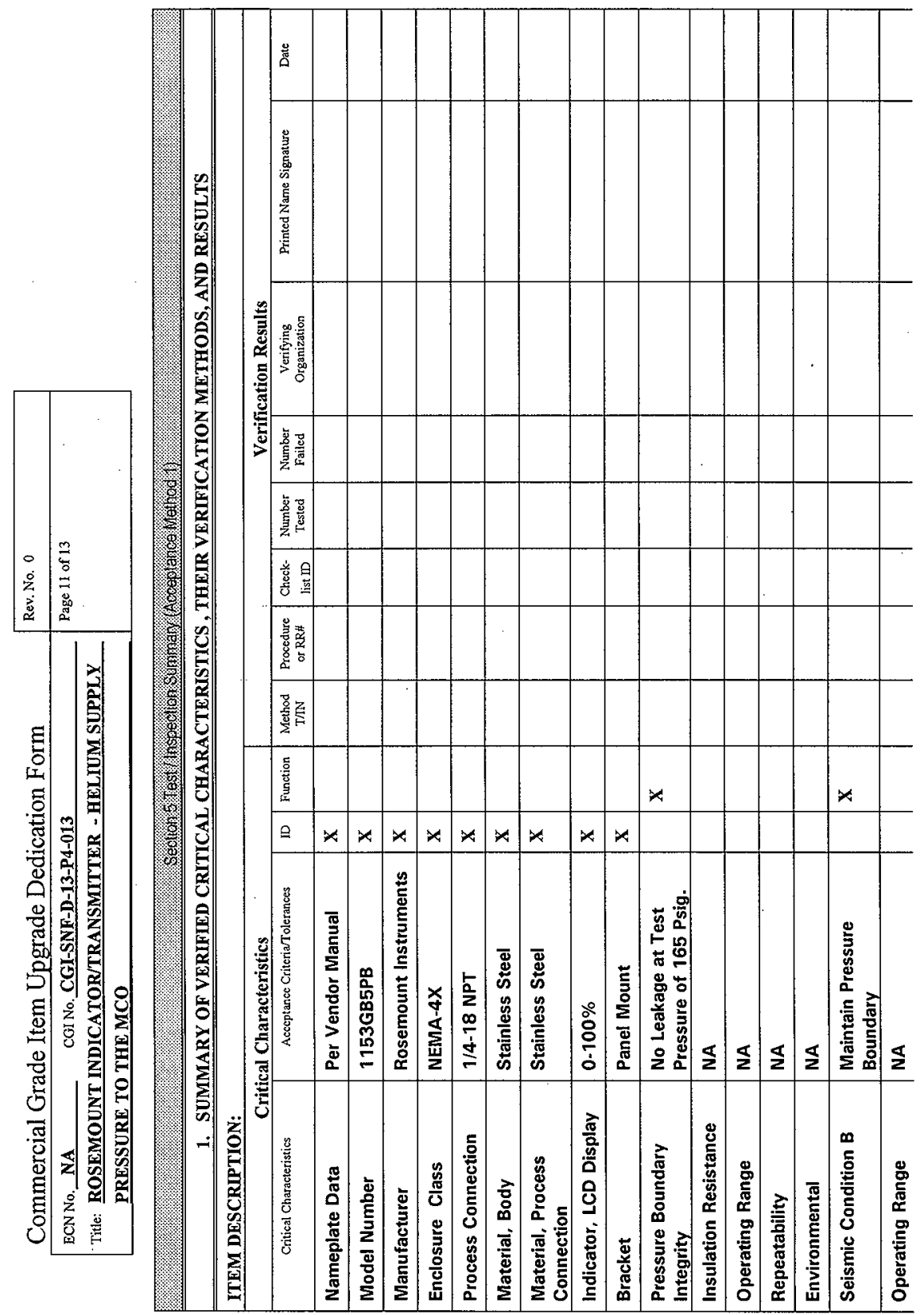




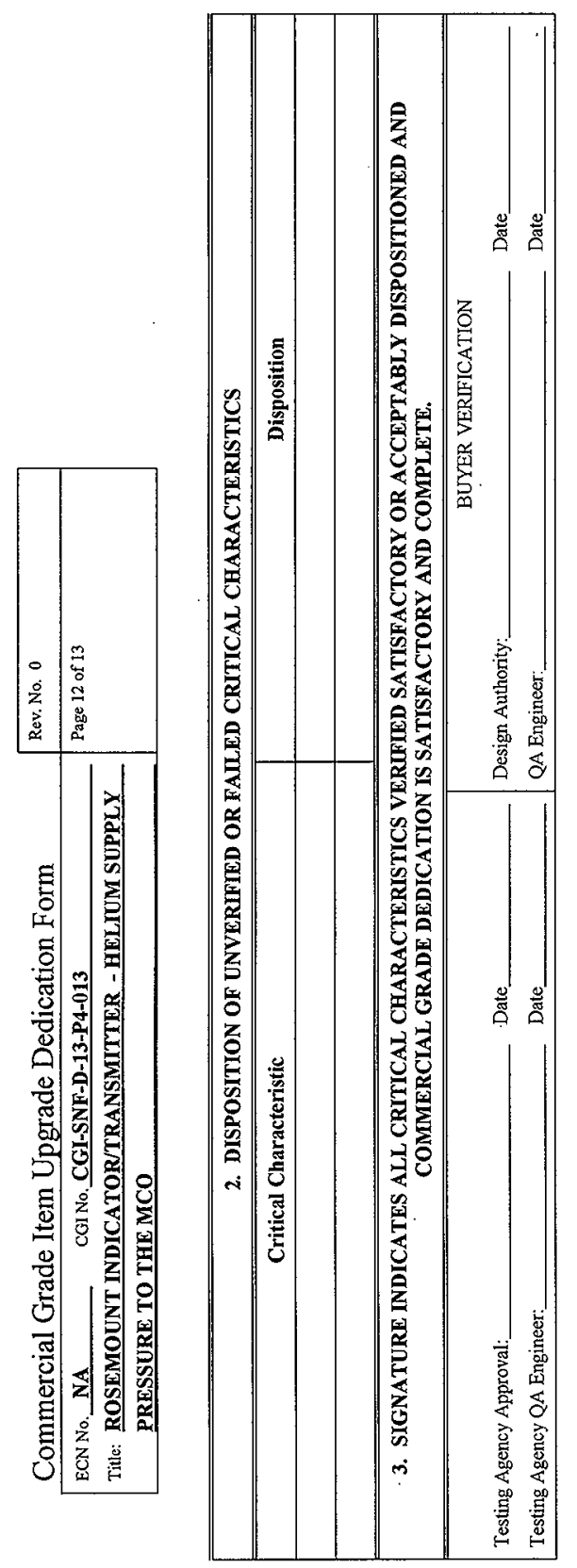

$\stackrel{\infty}{\circledR}$ 
Commercial Grade Item Upgrade Dedication Form

ECN No. NA CGINo.CGI-SNF-D-13-P4-013

Title: ROSEMOUNT INDICATOR/TRANSMITTER - FELIUM SUPPLY

PRESSURE TO THE MCO

\begin{tabular}{|c|c|}
\hline \multicolumn{2}{|l|}{ Name } \\
\hline Design Authority & ( \\
\hline QA & ( \\
\hline QC & ( \\
\hline Cog - Engineer & ( \\
\hline CGI Engineer & ( \\
\hline Procurement Engineer & ( \\
\hline \multicolumn{2}{|c|}{ Other } \\
\hline V. & 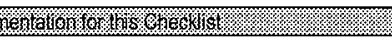 \\
\hline \multicolumn{2}{|c|}{\begin{tabular}{|l|l|} 
Initial Procurement Documents & For Critical Characteristics
\end{tabular}} \\
\hline \multicolumn{2}{|l|}{ [ ] Drawings: } \\
\hline \multicolumn{2}{|l|}{ [ ] Manuals (specify type \& number): } \\
\hline \multicolumn{2}{|l|}{ [ ] Design Calculations } \\
\hline \multicolumn{2}{|l|}{ [ ] Installation Instructions } \\
\hline \multicolumn{2}{|l|}{ [ ] Operation Instructions } \\
\hline \multicolumn{2}{|l|}{ [ ] Calibration Instructions } \\
\hline \multicolumn{2}{|l|}{ [ ] Manufacturer's Recommended Spare Parts List } \\
\hline \multicolumn{2}{|l|}{ [ I Other: } \\
\hline \multicolumn{2}{|l|}{ Procurement Documents } \\
\hline \multicolumn{2}{|l|}{ [ ] Certificate of Conformance/Compliance } \\
\hline \multicolumn{2}{|l|}{ [ ] Seismic Qualification Certificate } \\
\hline \multicolumn{2}{|l|}{ [ ] Environmental Qualification Certificate } \\
\hline \multicolumn{2}{|l|}{ [ ] Test Report (s): } \\
\hline \multicolumn{2}{|l|}{ [ ] Inspection Report (s): } \\
\hline \multicolumn{2}{|l|}{ [ ] CMTRs for ASME Pressure Retaining Materials } \\
\hline \multicolumn{2}{|l|}{ [ ] Valve Seat Leakage Report } \\
\hline \multicolumn{2}{|l|}{ [ ] Weld Records } \\
\hline \multicolumn{2}{|l|}{ [ I Material Traceability Record } \\
\hline [ ] Other: & \\
\hline
\end{tabular}

